\title{
PENGETAHUAN DAN KESIAPAN REMAJA PUTRI DALAM MENGHADAPI MENARCHE DI SD NEGERI NO 064023 MEDAN TAHUN 2017
}

\author{
Dina Indarsita, Yenni Purba \\ Jurusan Keperawatan Poltekkes Kemenkes Medan
}

\begin{abstract}
Abstrak
Menarche (haid pertama) merupakan menstruasi yang terjadi pertama kali pada seorang remaja, dimana hal ini umumnya terjadi pada usia antara 10 -16 tahun. Menarche juga salah satu tanda bahwa masa subur seorang remaja telah dimulai. Kesiapan menghadapi menarche adalah keadaan yang menunjukkan bahwa seseorang siap untuk mencapai salah satu kematangan fisik yaitu datangnya menstruasi pertama (menarche), hal ini ditandai dengan adanya pemahaman pengetahuan yang mendalam tentang proses menstruasi sehingga siap menerima dan mengalami menarche sebagai proses yang normal. Ketidaktahuan remaja tentang menstruasi dapat mengakibatkan anak sulit untuk menerima menarche. Tujuan dari penelitian ini adalah untuk mengetahui pengetahuan dan kesiapan remaja putri tentang menarche di SD Negeri No. 064023 Medan Tahun 2017. Penelitian ini menggunakan metode deskriptif dengan menggunakan rancangan cross sectional. Teknik sampling yang digunakan dalam penelitian ini yaitu total sampling dengan jumlah sampel sebanyak 82 orang. Hasil : Penelitian ini menunjukkan pengetahuan dengan kesiapan remaja putri menghadapi menarche tergantung seberapa banyak sumber informasi yang didapatkan. Karena semakin banyak informasi semakin banyak pengetahuan remaja tentang menarche. Remaja yang memiliki pengetahuan yang cukup kesiapannya menghadapi menarche positif. Simpulan : Pengetahuan remaja putri tentang menarche (menstruasi pertama) dikategorikan cukup sebesar 47,6\%. Sedangkan kesiapan remaja putri menghadapi menarche ( menstruasi pertama ) diketegorikan positif sebesar $56,1 \%$.
\end{abstract}

Kata kunci : Pengetahuan, Kesiapan Menghadapi Menarche, Remaja Putri

\section{PENDAHULUAN}

\section{Latar Belakang}

Populasi remaja di kota Medan berdasarkan data badan pusat statistik (BPS) kota medan. Tahun 2012 berjumlah 643.891 jiwa, tahun 2013 berjumlah 636.464 jiwa, tahun 2014 berjumlah 651.479 jiwa, tahun 2015 berjumlah 649.863 jiwa. Hal ini berarti populasi remaja di kota Medan mengalami peningkatan yang cukup pesat tahun 2013 ke tahun 2014, dan mengalami penurunan di tahun 2015 namun tidak dalam jumlah besar. Populasi remaja di kota Medan yang berusia 10-14 tahun berjumlah 89.405 jiwa.

Menarche merupakan menstruasi pertama yang biasa terjadi dalam rentang 10-16 tahun atau pada masa awal remaja di tengah masa pubertas sebelum memasuki masa reproduksi. Menstruasi adalah perdarahan periodik dan siklik dari uterus disertai pengelupasan (deskuamasi) endometrium. Menarche merupakan suatu tanda awal adanya perubahan lain seperti pertumbuhan lain seperti pertumbuhan payudara, pertumbuhan rambut daerah pubis dan aksila, serta distribusi lemak pada daerah pinggul.

Di Amerika serikat, sekitar 95\% remaja mempunyai tanda-tanda pubertas dengan menarche pada umur 12 tahun dan umur rata-rata 12,5 tahun yang diiringi dengan pertumbuhan fisik saat menrache. Di Maharashtra, India rata-rata usia menarche pada perempuan adalah 12,5 tahun. 24,92\% menarche dini,(10-11 tahun), 64,77\% menarche ideal (12-13 tahun) dan $10,30 \%$ menarche terlambat (14-15 tahun) (Rokade et al. 2009). Di Indonesia dan negara-negara Asia Tenggara,seorang remaja mendapat menarche rata-rata pada usia 12 tahun dan ada juga yang baru berusia 8 tahun sudah memulai siklus haid namun jumlah ini sedikit sekali. Usia paling lama mendapat menarche adalah 16 tahun. Usia mendapat menarche tidak pasti atau bervariasi, akan tetapi terdapat kecenderungan bahwa dari tahun ke tahun wanita remaja mendapat haid pertama pada usia yang lebih muda (Lestari, 2011).

Berdasarkan hasil riset kesehatan dasar tahun 2010, bahwa 5,2\% anak-anak di 17 provinsi di indonesia mengalami menarche di bawah usia 12 tahun. Sehingga Indonesia menempati urutan ke 15 dari 67 negara dengan penurunan usia menarche mencapai 0,145 tahun per dekade. Penelitiaan yang dilakukan di SMP N 30 Semarang pada tahun 2012 menunjukkan angka prevalensi menarche dini yaitu siswi yang mengalami menarche dibawah umur 12 tahun di sekolah tersebut sebesar 23,6\%. Penelitian di Kota Medan pada tahun 2009 menunjukkan 
bahwa usia rata-rata menarche pada remaja adalah 12,19 tahun (Rizvya Fildza, dkk, 2014).

Selama ini sebagian masyarakat merasa tabu untuk membicarakan tentang masalah menstruasi dalam keluarga, sehingga remaja awal kurang memiliki pengetahuan dan sikap yang cukup baik. Kesiapan mental sangat diperlukan sebelum menarche karena perasaan cemas dan takut akan muncul, selain itu juga kurangnya pengetahuan tentang perawatan diri yang diperlukan saat menstruasi.

Hasil dari beberapa penelitian yang dilakukan Aboyeji et all (2005), menunjukkan bahwa kebanyakan remaja mempunyai harapan yang lebih negatif terhadap menstruasi pertama (menarche) dan merespon menstruasi pertama (menarche) secara negatif. Hal ini dideskripsikan oleh subjek dengan perasaan secara negatif seperti merasa takut, terkejut, sedih, kecewa, malu, khawatir dan bingung.

Kasus lain yang memaparkan tentang dampak negatif dari ketidaktahuan remaja mengenai menstruasi pertama (menarche) dalam sebuah artikel, yaitu: " $S$ (11 tahun) ditemukan hampir pingsan di dalam kamar oleh orangtuanya dan segera dilarikan ke rumah sakit. Berhubung perawat terbatas dan sedang melayani pasien lainnya, maka segera dibawa masuk ke ruang tindakan dan ditangani oleh dokter. Menurut orangtuanya, mereka panik ketika melihat anaknya hampir pingsan dengan kondisi berdarah-darah. Mereka semakin panik karena anaknya tidak menjawab sewaktu ditanya apa yang terjadi. Keputusan yang pertama yang dipikirkan dalah membawa segera anaknya ke layanan kesehatan terdekat. Ternyata $S$ mendapatkan menstruasi pertama kalinya. Solusi sederhana yang diberikan doktere adalah memberinya pembalut, resep vitamin dan konsultasi tentang kesehatan reproduksi terhadap remaja dan orang tuanya (Respati, 2011).

Remaja yang akan mengalami menarche membutuhkan kesiapan mental yang baik. Kesiapan menghadapi menarche adalah keadaan yang menunjukkan bahwa seseorang siap untuk mencapai salah satu kematangan fisik yaitu datangnya menarche. Remaja yang belum siap menghadapi menarche akan timbul keinginan untuk menolak proses fisiologis tersebut, mereka akan merasa haid sebagai sesuatu yg kejam dan mengancam, keadaan ini dapat berlanjut ke arah yang lebih negatif(Jayanti et all,2011). Tetapi berbeda bagi mereka yang telah siap dalam menghadapi menarche, mereka akan merasa senang dan bangga, dikarenakan mereka menganggap dirinya sudah dewasa secara biologis (Yanti yusuf, dkk, 2014).

Menurut Budiati \& Apriastuti, 2012 berpendapat bahwa remaja belum mendapatkan pengetahuan dan informasi yang benar tentang menstruasi sehingga memiliki informasi yang salah tentang menstruasi, bahkan cenderung mengkaitkan menstruasi dengan sesuatu yang negatif. Ketidaktahuan anak tentang menstruasi dapat mengakibatkan anak sulit menerima menarche.

Hasil penelitian Leliana (2010), pengetahuan remaja putri SD Al-Azhar Medan terhadap kesiapan dalam menghadapi menarche menunjukkan bahwa responden yang memiliki pengetahuan baik sebanyak 21 orang
(95,5\%) dengan sikap positif dalam menghadapi menarche, pengetahuan baik dengan sikap negatif sebanyak 1 orang $(4,5 \%)$, pengetahuaqn tidak baik 12 orang $(63,2 \%)$ dengan sikap dalam menghadapi menarche, sedangkan pengetahuan tidak baik dengan sikap negatif dalam menghadapi menarche sebanyak 7 orang $(36,8 \%)$ menunjukkan adanya hubungan yang signifikan antara pengetahuan remaja putri terhadap kesiapan dalam menghadapi menarche.

Hasil penelitian Indra yudha 2012, kesiapan remaja putri menghadapi menarche menunjukkan bahwa sebagian besar responden menyatakan siap yakni 22 responden $(62,9 \%)$, sedangkan yang menyatakan tidak siap yakni 13 responden $(37,1 \%)$. Hal ini dikarenakan pengetahuan responden yang sudah cukup baik serta informasi yang didapat cukup baik sehingga menimbul kesiapan yang positif pada diri mereka.

Hasil penelitian Nur Fitri Jayanti, 2011, kesiapan remaja dalam menghadapi menarche di SD Negeri 1 Kretek Kecamatan Pangayungan Kabupaten Brebes, menunjukkan bahwa sebagian besar responden tidak siap dalam menghadapi menarche yaitu sebesar 48 anak $(92,30 \%)$, sedangkan sebagian kecil adalah siap dalam menghadapi menarche sebesar 4 anak (7,69\%). Kesiapan anak dalam menghadapi menarche secara emosional kesiapan anak dalam menghadapi menarche menunjukkan bahwa hampir s emua perasaan subjek mengalami cemas, bingung, takut dan deg-degan.

Berdasarkan studi pendahuluan yang dilakukan di SD Negeri No. 064023 Medan dari 8 siswi yang diwawancarai terdapat 4 siswi belum mendapat haid pertama (menarche), belum memiliki pengetahuan tentang haid pertama, dimana dari keluarga belum penyampaian informasi tentang haid pertama sehubungan dengan remaja putri belum mendapat haid pertama. 2 siswi mengatakan belum siap mendapatkan menstruasi pertama kali karena malu, takut, dan merasa minder. Sedangkan 2 siswi mengatakan sudah siap mendapatkan menstruasi pertama kali.

Berdasarkan data diatas, peneliti ingin meneliti tentang Pengetahuan dan Kesiapan Remaja Putri dalam Menghadapi Menarche di SD Negeri No. 064023 Medan Tahun 2017.

\section{Tujuan penelitian}

Penelitian ini bertujuan untuk mengetahui pengetahuan dan kesiapan remaja putri tentang Menarche di SD Negeri No. 064023 Medan Tahun 2017.

\section{Manfaat penelitian}

1. Dapat memberikan informasi kepada masyarakat terutama remaja putri dalam mempersiapkan dirinya dalam menghadapi menarche

2. Dapat memberikan masukan dan materi dalam melakukan penyuluhan dan pelayanan kesehatan reproduksi remaja khususnya menarche. 


\section{GAMBARAN LOKASI PENELITIAN}

Penelitian ini dilakukan di SDN 064023 Medan yang berlokasi di Jl. Jamin Ginting Km 12, Kemenangan Tani, Kec. Medan Tuntungan, Kota Medan. SDN 064023 Medan merupakan sekolah terakreditasi B.

SDN 064023 Medan terdiri dari 9 ruang kelas, 1 perpustakaan dan 1 kantor kepala sekolah serta ruang BP yang berada di ruangan kepala sekolah. SDN 064023

1. Pengetahuan memiliki luas tanah $1.600 \mathrm{~m}^{2}$. Jumlah siswa keseluruhan SDN 064023 yaitu 446 orang (kelas I-VI), siswa perempuan berjumlah 235 orang dan siswa laki-laki 211 orang. Sedangkan jumlah guru di SDN 064023 yaitu 19 orang. SDN 064023 menggunakan kurikulum 2013.

Tabel. 1

Distribusi Frekuensi Pengetahuan Tentang Menarche

Di SD Negeri No. 064023 Medan Tahun 2017

\begin{tabular}{lll}
\hline Pengetahuan & Frekuensi & Persentase \\
\hline Baik & 16 & 19.5 \\
Cukup & 39 & 47.6 \\
Kurang & 27 & 32.9 \\
\hline Total & 82 & 100.0 \\
\hline
\end{tabular}

Berdasarkan tabel 1 diatas dapat diketahui bahwa ada 39 orang $(47,6 \%)$ responden yang tahu tentang menarche.

2. Kesiapan

Tabel 2

Distribusi Frekuensi Kesiapan Remaja Putri dalam Menghadapi Menarche di SD Negeri No. 064023 Medan Tahun 2017

\begin{tabular}{lll}
\hline Kesiapan & Frekuensi & Persentase \\
\hline Positif & 46 & 56.1 \\
Negatif & 36 & 43.9 \\
\hline Total & 82 & 100.0 \\
\hline
\end{tabular}

Berdasarkan tabel 2 diatas dapat diketahui bahwa ada 46 orang $(56,1 \%)$ responden yang siap dalam menghadapi menarche.

3. Sumber Informasi

Tabel 3

Distribusi Frekuensi Sumber Informasi Tentang Menarche di SD Negeri No. 064023 Medan Tahun 2017

\begin{tabular}{lll}
\hline Sumber Informasi & Frekuensi & Persentase \\
\hline Media cetak & 20 & 24.4 \\
Media elektronik & 15 & 18.3 \\
Keluarga & 36 & 43.9 \\
Tenaga kesehatan & 11 & 13.4 \\
\hline Total & 82 & 100.0 \\
\hline
\end{tabular}

Berdasarkan tabel 3 diatas dapat diketahui bahwa responden yang pernah mendengar tentang menarche dari keluarga sebanyak 36 orang $(43,9 \%)$, dan tenaga kesehatan sebanyak 11 orang $(13,4 \%)$.

4. Pengetahuan dengan Kesiapan

Tabel 4

Distribusi Frekuensi Kesiapan Dalam Menghadapi Menarche

Berdasarkan Pengetahuan Responden di SD Negeri No. 064023 Medan Tahun 2017

\begin{tabular}{l|c|c|c}
\hline \multirow{2}{*}{ Pengetahuan } & \multicolumn{2}{|c|}{ Kesiapan } & \multirow{2}{*}{ Total } \\
\cline { 2 - 3 } & Positif & Negatif & 16 \\
\hline Baik & 15 & 1 & 39 \\
Cukup & 29 & 10 & 27 \\
Kurang & 2 & 25 & 82 \\
\hline Total & 46 & 36 & \\
\hline
\end{tabular}


Berdasarkan tabel 4 diatas dapat diketahui bahwa dari 39 orang responden yang berpengetahuan cukup tentang menarche ada 29 orang yang berpengetahuan cukup siap dalam menghadapi menarche.

5. Pengetahuan dengan Sumber Informasi

Tabel 5

Distribusi Frekuensi Pengetahuan Tentang Menarche Berdasarkan Sumber Informasi di SD Negeri No. 064023 Medan Tahun 2017.

\begin{tabular}{l|c|c|c|c|c}
\hline \multirow{2}{*}{ Pengetahuan } & \multicolumn{4}{|c|}{ Sumber informasi } & \multirow{2}{*}{ Total } \\
\cline { 2 - 5 } & Media cetak & $\begin{array}{c}\text { Media } \\
\text { elektronik }\end{array}$ & Keluarga & $\begin{array}{c}\text { Tenaga } \\
\text { Kesehatan }\end{array}$ & \\
\hline Baik & 7 & 1 & 6 & 2 & 16 \\
Cukup & 10 & 12 & 12 & 5 & 39 \\
Kurang & 3 & 2 & 18 & 4 & 27 \\
\hline Total & 20 & 15 & 36 & 11 & 82 \\
\hline
\end{tabular}

Berdasarkan tabel 5 diatas dapat diketahui bahwa dari 39 orang responden yang berpengetahuan cukup tentang menarche ada : 12 orang responden yang mendapatkan sumber informasi tentang menarche dari keluarga dan 12 orang responden yang mendapatkan sumber informasi tentang menarche dari media elektronik

6. Kesiapan dengan Sumber Informasi

Tabel 6

Distribusi Frekuensi Kesiapan dalam Menghadapi Menarche Berdasarkan Sumber Informasi di SD Negeri No. 064023 Medan Tahun 2017.

\begin{tabular}{|c|c|c|c|c|c|}
\hline \multirow[b]{2}{*}{ Kesiapan } & \multicolumn{4}{|c|}{ Sumber informasi } & \multirow[b]{2}{*}{ Total } \\
\hline & Media cetak & $\begin{array}{c}\text { Media } \\
\text { elektronik }\end{array}$ & Keluarga & $\begin{array}{c}\text { Tenaga } \\
\text { kesehatan }\end{array}$ & \\
\hline Positif & 15 & 9 & 17 & 5 & 46 \\
\hline Negatif & 5 & 6 & 19 & 6 & 36 \\
\hline Total & 20 & 15 & 36 & 11 & 82 \\
\hline
\end{tabular}

Berdasarkan tabel 6 diatas dapat diketahui bahwa dari 46 orang responden yang siap menghadapi menarche ada 17 orang yang mendapatkan informasi tentang menarche dari keluarga dan 15 orang dari media cetak.

\section{PEMBAHASAN}

\section{Pengetahuan}

Pengetahuan merupakan hasil dari tahu dan ini terjadi setelah orang mengadakan penginderaan terhadap suatu objek tertentu. Dari tabel 1 dapat diketahui bahwa mayoritas responden berpengetahuan cukup tentang menarche sebanyak 39 orang $(47,6 \%)$ dan minoritas responden berpengetahuan baik tentang menarche sebanyak 16 orang (19,5\%).

Dari hasil penelitian tingkat pengetahuan responden mengenai pengetahuan remaja putri tentang menarche di SD Negeri No. 064023 Medan termasuk dalam kategori pengetahuan cukup sebanyak 39 orang $(47,6 \%)$. Ini menunjukkan bahwa secara umum responden sudah cukup tahu mengenai pengetahuan tentang menarche. Hal ini dipengaruhi informasi dan pendidikan tentang menarche.

Hasil analisa yang didapatkan bahwa remaja putri yang berpengetahuan cukup banyak mendapat informasi dari keluarga dan media elektronik.

Hasil penelitian Yanti Yusuf dkk tentang hubungan pengetahuan menarche dengan kesiapan remaja putri menghadapi menarche di SMP Negeri 3 Tidore kepulauan menunjukan bahwa sebagian besar responden berpengetahuan cukup dikarenakan sebagian besar informasi yang diperoleh dari orang tua dan teman sebanyak 19 responden $(54,3 \%)$. Menurut Notoatmojodjo (2003), dimana semakin banyak informasi yang didapat seseorang maka akan semakin baik pengetahuan seseorang terutama pengetahuan mengenai menarche.

Selama ini sebagian masyarakat merasa tabu untuk membicarakan tentang masalah menstruasi dalam keluarga, sehingga remaja awal kurang memiliki pengetahuan yang kurang baik tentang perubahanperubahan fisik dan psikologis terkait menarche, selain itu juga kurangnya pengetahuan tentang perawatan diri yang diperlukan saat menstruasi.

Pengalaman merupakan guru terbaik. Pepatah tersebut dapat diartikan bahwa pengalaman merupakan sumber pengetahuan atau pengalaman itu suatu cara untuk memperoleh kebenaran pengetahuan. Oleh sebab itu pengalaman pribadi pun dapat digunakan sebagai upaya untuk memperoleh pengetahuan. Hal ini dilakukan dengan cara mengulang kembali pengalaman 
yang diperoleh dalam memecahkan permasalahan yang dihadapi pada masa lalu.

Penyebab lain adalah keadaan lingkungan yang tidak mendukung, misalnya kurangnya persediaan buku-buku tentang kesehatan dan kesehatan reproduksi khususnya tentang menarche di perpustakaan sekolah. Hal ini sesuai dengan pendapat Notoatmodjo (2002:121) yang mengatakan bahwa faktor lingkungan sering merupakan faktor dominan yang mewarnai prilaku seseorang.

Menurut Kartono (2006) dalam Buku Psikologi Wanita Mengenal Gadis Remaja dan Wanita Dewasa. Orang yang mempunyai sumber informasi yang lebih banyak akan memiliki pengetahuan yang lebih luas pula. Informasi dapat diperoleh di rumah, di sekolah, lembaga organisasi, media cetak dan tempat pelayanan kesehatan.

Jadi sebagian besar pengetahuan responden yang cukup dipengaruhi oleh kesadaran dan minat baca yang baik yang diterima remaja putri yang berasal dari pesatnya kemajuan tehknologi informasi baik media cetak maupun media elektronika sehingga banyak dari mereka yang berwawasan luas.

\section{Kesiapan remaja menghadapi menarche}

Berdasarkan tabel 2 dapat diketahui bahwa responden memiliki kesiapan positif sebanyak 46 orang $(56,1 \%)$ dan responden memiliki kesiapan negatif sebanyak 36 orang $(43,9 \%)$. Kesiapan remaja menghadapi menarche di SD Negeri No. 064023 Medan.

Dari hasil penelitian ditemukan 46 responden memiliki kesiapan yang positif. Dapat bisa disimpulkan bahwa kesiapan remaja putri dalam kategori positif dalam menghadapi menarche. kesiapan yang positif disebabkan karena sumber informasi yang diperoleh responden paling banyak adalah dari keluarga yaitu sebanyak 36 responden $(43,9 \%)$.

Hal tersebut diperkuat dengan penelitian Jayanti dan Purwanti (2011) tentang Deskripsi FaktorFaktor Yang Mempengaruhi Kesiapan Anak Dalam Menghadapi Menarche Di SD Negeri 1 Kretek Kecamatan Paguyangan Kabupaten Brebes didapatkan bahwa dari 52 responden yang siap dalam menghadapi menarche sebanyak 4 anak, dan semua anak (100\%) mendapatkan informasi tentang menarche dari keluarga

Kesiapan remaja putri untuk menerima menarche tergantung beberapa hal, salah satunya dipengaruhi oleh faktor perilaku orang tua sebagian ibu mengajari anak perempuan mereka tentang menstruasi, seperti usia mendapatkan menstruasi, lama menstruasi, dan pemeliharaan kesehatan selama menstruasi (Suci Musvita Ayu, 2011). Hal ini berarti peran orangtua yang mendasarkan dalam kehidupan remaja putri. Penilaian - penilaian terhadap pengetahuan dan kesiapan didasarkan pada kriteria yang telah ada. Jadi walaupun informasi sudah tersebar secara bebas, tetap baik tidaknya pengetahuan tergantung pada kemampuan masing - masing individu dalam pemahaman, penghayatan, kesediaan, hal ini sesuai dengan mengenai teori kesiapan.

Kesiapan menghadapi menarche merupakan salah satu kondisi yang memerlukan penyesuaian fisik dan psikologis dari remaja putri. Maka dengan adanya sumber-sumber informasi sosial disekitar remaja putri akan dapat meningkatkan kesiapan remaja putri dalam menghadapi menarche.

\section{Pengetahuan dan Kesiapan}

Dari tabel 4 diatas dapat diketahui bahwa berdasarkan pengetahuan dengan kesiapan responden mayoritas pengetahuan cukup dengan kesiapan positif dalam menghadapi menarche sebanyak 29 orang dan minoritas berpengetahuan kurang dengan kesiapan positif dalam menghadapi menarche sebanyak 2 orang. Semua responden memiliki kesiapan yang positif dan dengan pengetahuan yang berbeda-beda.

Dari hasil penelitian didapatkan 29 responden pengetahuan cukup memiliki kesiapan yang positif dalam menghadapi menarche. Dapat disimpulkan bahwa kesiapan dipengaruhi oleh pengetahuan seseorang dan jika pengetahuan seseorang baik maka kesiapannya positif. Pengetahuan yang diperoleh remaja tentang menstruasi akan mempengaruhi persepsi remaja tentang menstruasi pertama (menarche). Remaja yang akan mengalami menstruasi pertama (menarche) membutuhkan kesiapan mental yang baik.

\section{Pengetahuan dengan Sumber Informasi}

Berdasarkan tabel 5 diatas dapat diketahui bahwa pengetahuan dengan sumber informasi dari keluarga dan media elektronik mayoritas berpengetahuan cukup sebanyak 12 orang dan minoritas responden berpengetahuan baik mendapat sumber informasi dari media elektronik sebanyak 1 orang.

Dari hasil penelitian didapatkan 12 responden berpengetahuan cukup mendapat sumber informasi dari keluarga. Dapat disimpulkan bahwa semakin banyak sumber informasi yang kita terima dapat meningkatkan pengetahuan yang lebih baik dan sumber informasi berhubungan dengan pengetahuan.

\section{Kesiapan dengan Sumber Informasi}

Dari tabel 6 diatas dapat diketahui bahwa kesiapan dalam menghadapi menarche dengan sumber informasi dari keluarga mayoritas memiliki kesiapan positif sebanyak 17 orang dan minoritas responden memiliki kesiapan negatif mendapat sumber informasi dari media cetak sebanyak 5 orang.

Dari hasil penelitian didapatkan 17 responden memiliki kesiapan positif mendapat sumber informasi dari keluarga. Dapat disimpulkan bahwa sumber informasi dengan kesiapan yang positif yang paling banyak didapat responden adalah dari keluarga hal ini menunjukkan bahwa dukungan dari keluarga sangat baik di berikan kepada remaja putri untuk menghadapi menarche. 


\section{KESIMPULAN}

1. Hasil penelitian menunjukkan bahwa tingkat pengetahuan remaja putri tentang menarche (menstruasi pertama) dikategorikan cukup sebanyak 39 orang $(47,6 \%)$ sedangkan kategori kurang sebanyak 16 orang $(19,5 \%)$.

2. Hasil penelitian menunjukkan kesiapan remaja dalam menghadapi menarche dikategorikan kesiapan positif sebanyak 46 orang $(56,1 \%)$ sedangkan kategori kesiapan negatif sebanyak 36 orang $(43,9 \%)$.

\section{SARAN}

1. Diharapkan agar responden lebih aktif mencari informasi tentang menarche terutama tanda awal menarche, faktor-faktor mempengaruhi menarche dan gangguan psikologis saat menarche dari sumber-sumber informasi yang bisa digunakan.

2. Disarankan kepada pihak sekolah untuk meningkatkan pengetahuan siswi dan penyuluhan kesehatan dengan menjalin hubungan dengan puskesmas serta tenaga kesehatan lainnya agar remaja putri benar-benar paham dan mengerti tentang menarche. Dalam hal ini disarankan kepada BP agar meningkatkan program pendidikan kesehatan dengan membentuk sebuah unit kesehatan sekolah (UKS).

\section{DAFTAR PUSTAKA}

BPS Kota Medan. 2014. Medan Dalam Angka. Medan. BPS Kota Medan. 2015. Medan Dalam Angka. Medan. BPS Kota Medan. 2016. Medan Dalam Angka. Medan. Budiati, S., dan Apriastuti. 2012. Hubungan Tingkat Pengetahuan Ibu Tentang Kesehatan Reproduksi Remaja dengan Kesiapan Anak Menghadapi Masa Pubertas di Dukuh Carikan. Magelang: Jurnal Kebidanan Vol IV. http://journal.akideub.ac.id/index/php/57. (Diakses tanggal 7 Februari 2017)

Ellya, E., dkk. 2016. Kesehatan Reproduksi Wanita. Jakarta: Trans Info Media.

Fildza, R., dkk, 2014. Analisis faktor yang berhubungan dengan kejadian menarche pada siswi di SMP swasta Harapan 1 dan 2 Medan. http://jurnal.usu.ac.id/index.php/gkre/article/downlo $\mathrm{ad} / 8574 / 4350$.

(Diakses tanggal 7 Februari 2017).

Jayanti dan Purwanti . 2011. Deskripsi Faktor-Faktor Yang Mempengaruhi Kesiapan Anak Dalam
Menghadapi Menarche Di SD Negeri 1 Kretek Kecamatan Paguyangan Kabupaten Brebes. Purwokerto: Akademi Kebidanan YLPP Purwokerto. Tersedia dalam file:///C:/Users/User/Downloads/11-19-1-SM.pdf. (Diakses tanggal 17 januari 2017).

Leliana. 2010. Pengetahuan Remaja Putri SD AL-Azhar Terhadap Kesiapan dalam Menarche. Medan: Prodi S1 Keperawatan Universitas Negeri Medan. Tersedia dalam http://www.library.unimed.ac.id. (Diakses tanggal 19 Januari 2017).

Nurhayati, I. 2015. Panduan Penyusunan Karya Tulis Ilmiah. Medan: Politeknik Kesehatan Kemenkes.

Proverawati, A., dan Misaroh, S. 2015. Menarche Menstruasi Pertama Penuh Makna. Yogyakarta: Nuha medika.

Respati. 2011. Problematika Remaja Akibat Kurangnya Informasi Kesehatan Reproduksi. Jakarta: Fakultas Psikologi Universitas Esa Unggul. http://www.esaunggul.ac.id/wpcontent/upload/2012 /12esaunggul.ac.co.id.edit.pdf (Diakses tanggal 17 januari 2017)

Sastroasmoro, S., dan Ismael, S. 1995. Dasar-Dasar Metodologi Penelitian Klinis. Jakarta: Binarupa Aksara.

Setiawati, N., dan Suratini. 2014. Hubungan peran orang tua dengan kesiapan menghadapi

menarche pada siswi kelas IV dan V di SDN Serangan Yogyakarta.

http://opac.unisayogya.ac.id/1152/1/Naskah\%20 Publikasi\%20fix.pdf. (Diakses tanggal 19 Januari 2017).

Wawan, A., dan Dewi, M. 2016. Teori dan Pengukuran Pengetahuan, Sikap dan Perilaku Manusia. Yogyakarta: Nuha Medika.

Winkjosastro. 2008. Ilmu Kandungan Edisi 2.Jakarta: EGC Yudha, I. 2012 Hubungan Antara Pengetahuan Dengan Kecemasan Menghadapi Menarche Pada Siswi Kelas VI. http://digilib.unimus.ac.id/dowload.php?id=5718. (Diakses tanggal 7 Januari 2017)

Yusuf, Y., dkk. 2014. Hubungan pengetahuan menarche dengan kesiapan remaja putri menghadapi menarche di SMP Negeri 3 Tidore Kepulauan. http://ejournal.unsrat.a c.id/index.php/jkp/article/download/5272/4785.

(Diakses tanggal 14 desember 2016). 